\title{
The Analysis of Economic, Financial and Political Factors Effecting The Changes of Ratings Assessed by The Credit Rating Agencies: A Survey for Turkey
}

Funda H. Sezgin*, Tülin Atakan**, Cem Değirmenci***

* Istanbul University, Istanbul, Turkey*, Istanbul University, Istanbul, Turkey**, Istanbul University, Istanbul, Turkey***

E-mail: fsezgin@istanbul.edu.tr*,f.tulinatakan@gmail.com**,degirmencic@gmail.com***

Copyright (C) 2015 Funda H. Sezgin, Tülin Atakan, Cem Değirmenci. This is an open access article distributed under the Eurasian Academy of Sciences License, which permits unrestricted use, distribution, and reproduction in any medium, provided the original work is properly cited.

\begin{abstract}
Credit rating agencies examine the credit risks of countries according to certain criteria and present the rating results with certain grading symbols. Because financial actors prefer countries and industries with high investment grades as per the given ratings, credit ratings become even more important for developing countries which require capital. This study conducts a logistic regression model separately for the three well-known Rating Agencies, namely Moody's, S\&P and Fitch, to determine the economic, financial and political parameters that have an influence on changes in credit ratings given to Turkey by those institutions, for the period of 2000-2014. The results of the analysis put forward that, the gross domestic product (GDP) and the political risk index (PRI) variables are equally significant for each of the three credit rating agencies; and in addition, the stock market return (SMR) and the current account balance (CAB) for S\&P, the external debt (ED) and the unemployment rate (UM) for Moody's; and the external debt (ED) and the real interest rates (RIR) for Fitch, are also determined to be significant in changes in credit ratings.
\end{abstract}

Keywords: Sovereign Credit Rating, Credit Rating Changes, Credit Rating Agencies, Economic, Financial and Political Variables, Logistic Regression

JEL: C01, G24, O50

\section{Kredi Derecelendirme Kuruluşlarının Not Değişimlerinde Ekonomik, Finansal ve Politik Faktörlerin Etkilerinin Analizi: Türkiye Örneği}

\section{ÖZET}

Kredi derecelendirme kuruluşları, ülkelerin kredi risklerini belli kriterlere göre incelemekte ve belirlediği sembollerle değerlendirme sonuçlarını açıklamaktadır. Finansal aktörler, belirlenen notlar doğrultusunda yüksek yatırım düzeyinde bulunan ülke ve sektörlere yöneldikleri için, kredi notu özellikle sermayeye ihtiyaç duyan gelişmekte olan ülkeler için daha da önem taşımaktadır. Bu çalışmada, Türkiye'ye Moody, S\&P ve Fitch tarafından verilen notların, 2000-2014 dönemi için not değişimlerini etkileyen ekonomik, finansal ve politik değişkenleri 
belirlemek amaçlı üç kuruluşun her birine yönelik lojistik regresyon modeli uygulanmıştır. Analiz sonucunda, her üç kuruluş için GDP ve PRI değişkenlerinin ortak önemli olduğu, S\&P için ayrıca SMR ve CAB değişkenleri, Moody’s için ED ve UM değişkenleri ve Fitch için ED ve RIR değişkenlerinin not değişimde önemli olduğu belirlenmiştir.

Anahtar Kelimeler: Ülke Kredi Notu, Kredi Notu Değişimi, Kredi Reyting Kuruluşları, Ekonomik, Finansal ve Politik Değișkenler, Lojistik Regresyon

\section{INTRODUCTION}

One of the major problems in the economies of developing countries is capital inadequacy due to the lack of financing from external sources. In recent years, the risk and creditworthiness are significantly mentioned as the main reasons behind this capital inadequacy which constitutes a long-lasting economic problem for countries. In this context, the credit rating is the determination and presentation of various risks related with the country or industry at which capital owners wish and prefer to invest.

External rating is the system used by international credit rating agencies to assess a country's level of creditworthiness and external borrowing capability. Due to its international nature, this system reveals the economic position of a country relative to other countries (Tattersall and Smith, 2005:47).

The credit rating spans a wide range of areas including banks, government institutions, municipalities, and finally countries as a whole. Even though there exist large number of credit rating agencies today, Moody's, Standard \& Poor's, and Fitch are the major institutions of the credit rating sector. The main aim of those agencies is to present correct, consistent and reliable information to international markets. Agencies which present biased information and act dishonestly that results in destroying their trustworthiness, lose this attribute.

The aim of this study is to examine and put forward which economic, financial, and political fundamental indicators in Turkey are significant determinants for changes in the credit ratings given by the Moody's, Standard \& Poor's and Fitch. The risk coefficients of variables considered, are calculated by means of logistic regression model; and the risk rankings for each of the three agencies are determined.

\section{SOVEREIGN CREDIT RATING, ITS IMPORTANCE AND TURKEY}

The sovereign credit rating denotes the level of risk for the investment environment in a country. The credit rating in Turkey dates back to the year of 1991. After the deregulation of capital movements in 1989, Turkey experienced an enormous inflow of foreign capital to the country. Meanwhile, Turkey entered into the international bond markets. With the US-backed financing opportunities, which were initially aimed for defense purposes, the bond sales in Euro markets became gradually widespread. By the inception of borrowing facilities from global markets, Turkey's credit rating process had started. Even though Turkey was first rated 
in 1989, the announcement of the credit rating was delayed until 1992, due to the issues of Yankee bonds and Japanese Samurai bonds.

The current rating methodologies of international credit rating agencies do not possess reliable and well-planned rating properties to assess countries, and moreover, these rating agencies did not assess developing countries until 1990s. Considering past data, Turkey's credit ratings have steadily and continuously been below the "investment grade", except in 1992, when the initial credit rating was released and in 1993. In the financial crisis of 1994, S\&P and Moody's downgraded consecutively Turkey's credit rating from the "investment grade" (BBB) to the "speculative grade" $(\mathrm{B}+)$. In 1995, Fitch downgraded Turkey's credit rating from the "investment grade" (BBB) to the "speculative grade" (BB-); and to (B+) in 1996. These ratings remained in the same grades until the S\&P upgraded Turkey's rating to (BB-) in 2004. Then, the Moody's upgraded Turkey's rating to (Ba3) and the Fitch to (BB-) in 2005. After the global crisis, Turkey's credit rating for 2012 was assessed as (BB) with "stable" outlook by the S\&P, as (Ba1) with "positive" outlook by Moody's, as (BB+) with "stable" outlook by Fitch, and as (BB) with "stable" outlook by Japan Credit Rating Agency (JCR). As of the end of 2013, Turkey was assessed as (BBB) by the S\&P, as (Baa3) by Moody's, and finally as (BBB) with Fitch, with all of them assigning the same outlook as "stable". The ratings and outlooks for 2014 were all the same as 2013 for Turkey, only with an exception of the S\&P assessing (BBB) with a "negative" outlook. The political and economic uncertainties had been the main determinants in Turkey's above-mentioned credit ratings.

Today, many countries prefer external borrowing from international markets. Thus, at this stage, the credit ratings have an important role. A country with a high credit rating is considered to have a high debt repayment capacity and capability. Consequently, it becomes relatively easier to obtain financing through external borrowing. The benefits of credit rating function to the economic life may be summarized as follows:

Constitution of financial markets which develop and operate with reliability, trustworthiness, and stability in the economy.

> Providing external financing sources for the economy and enabling the integration of domestic markets with the international markets.

$>$ While limiting the general risk level in the economy, increasing the efficiency of financial transactions and ensuring more effectiveness in the financing for growth (Gallati, 2003: 260).

Before investing, the main goal of investors is to conduct the risk-return trade-off analysis and investigate the risk tendencies of the potential investments. At this point, credit rating agencies present a safer scope of investment for investors, by providing the financial and economic strengths of a country with a more understandable context.

Although each of the three rating agencies indicate that similar factors (parameters) are being considered for credit ratings, and each of their reports, with emphasizing on those factors, present certain country outlooks; the details of the reports, regarding their methods and the level of importance and influence among those factors, are not released to the public. This 
issue is a point of criticism towards these rating agencies. Moreover, particularly in the case of upgrading the ratings, such agencies also make optimistic predictions and forecasting about the future of a country's economy.

\begin{tabular}{|l|l|l|l|l|l|l|l|}
\cline { 2 - 8 } \multicolumn{1}{c|}{} & $2000-$ & $2002-$ & $2004-$ & $2006-$ & $2008-$ & $2010-$ & $2012-$ \\
\cline { 2 - 8 } & 2002 & 2004 & 2006 & 2008 & 2010 & 2012 & 2014 \\
\hline Fitch & $\downarrow$ & $\uparrow$ & $\uparrow$ & $\rightarrow$ & $\uparrow$ & $\rightarrow$ & $\uparrow$ \\
\hline S\&P & $\downarrow$ & $\uparrow$ & $\uparrow$ & $\downarrow$ & $\uparrow$ & $\rightarrow$ & $\rightarrow$ \\
\hline Moody's & $\rightarrow$ & $\rightarrow$ & $\uparrow$ & $\uparrow$ & $\uparrow$ & $\uparrow$ & $\uparrow$ \\
\hline
\end{tabular}

Table 1: Changes in Turkey's Ratings during 2000-2014

\section{CREDIT RATING AGENCIES, THE RATING CRITERIA AND THE PROCESS}

There exist various quantitative and qualitative criteria, which international credit agencies refer to, during their assessment for determining the credit rating. These criteria include economic evaluations, such as the flexibility of national economy, the growth potential and the economic stability, debt ratios and the capability of debt repayments. Besides, criteria include political evaluations, such as the political stability of a country, the conditions of national leaders, the developments and changes in foreign policies, risks in the political agenda, and the Central Bank's degree of independence, etc. In conclusion, detailed credit analyses of rating agencies are conducted by examining a country's history of economic and political performance and the present conditions (Ward, 2002:32).

Credit ratings are determined by a credit committee's assessment of quantitative and qualitative analyses which are previously conducted by analysts. The credit rating decided by this committee, is shared with the evaluated (rated) institutions and organizations (Scott, 2005:37).

After the collapse in the US economy in the period of 1837-1841, a "Credit-Rating" practice was initiated by L. Tappan for companies that fail to fulfill their obligations. Then in 1900, John Moody published a handbook including corporate data and gave guidance to investors' for their decisions and choices. In 1909, Moody rated companies' debts as "A", "B", "C", and other ratings. Thus, the first rating practice began; and in 1913, Fitch had founded the "first" credit rating agency - a company which evaluated other companies' performances. Following that, in 1941, the S\&P was founded and those became the most influential three rating agencies today. Other than these, the Duff \& Phelps Agency and the Dominion Bond Agency are also two important institutions in this area.

The credit assessment by each of the three rating agencies is composed of two basic components, namely the "credit rating" and the "outlook". The "credit rating" of an economy is used to indicate the creditworthiness and the conditions of an economy in the long-run; whereas the "outlook" is an evaluation, based on short-term macroeconomic activities of the same economy. Hence, while a country has a credit rating of (BBB-), the agency that declared this credit rating, shares its opinions on that country's economy by periodically presented reports and states the "outlooks", such as "stable", "positive", or "negative", which contain information about the risks related to the short-term macroeconomic conditions (Nye and Eke, 2004, s.4) 
The credit rating methodology works similarly in different credit rating agencies. Many agencies determine the "credit rating" of a country through five main factors, which constitute the political, economic, external, financial and monetary scores, but it is not declared that which factor has a higher importance or priority on the determination of the "credit rating". These five scores are then combined according to different criteria of the agencies, and the country's political and economic profile that is related with the government situation (such as, the stability of the national economy, the strong structure of public institutions, and the effective decision-making capability/activity) is thereby formed. Also, the profile that is related with the flexibility and performance (such as, the fiscal balance and the sustainability of the government debt) is formed. These two different profiles are then used for determining an "indicative credit rating level". The prevalent expectation is that when a country's credit rating in terms of foreign currency is compared with other countries in similar conditions, the credit rating of that country will be either one grade above or below the "indicative rating level". For instance, if a country's political and economic profile is assessed as "partially strong", and its flexibility and performance profile as "very strong", then the country will most likely be rated one grade below or above the (AA-).

\begin{tabular}{|c|c|c|c|}
\hline Fitch & S\&P & Moody's & Investment/Speculative Grade \\
\hline AAA & AAA & Aaa & \multirow[b]{10}{*}{ Investment } \\
\hline $\mathrm{AA}+$ & AA+ & Aa1 & \\
\hline AA & AA & $\mathrm{Aa2}$ & \\
\hline AA- & AA- & Aa3 & \\
\hline$A+$ & $A+$ & A1 & \\
\hline A & A & $A 2$ & \\
\hline$A-$ & A- & A3 & \\
\hline $\mathrm{BBB}+$ & $\mathrm{BBB}+$ & Baa1 & \\
\hline BBB & BBB & Baa2 & \\
\hline BBB- & BBB- & Baa3 & \\
\hline $\mathrm{BB}+$ & $\mathrm{BB}+$ & Ba1 & \\
\hline $\mathrm{BB}$ & $\mathrm{BB}$ & $\mathrm{Ba} 2$ & \\
\hline BB- & BB- & Ba3 & \\
\hline $\mathrm{B}+$ & $\mathrm{B}+$ & B1 & \\
\hline$B$ & $B$ & $B 2$ & \\
\hline B- & B- & B3 & \\
\hline $\mathrm{CCC}+$ & $\mathrm{CCC}+$ & Caa1 & \\
\hline $\mathrm{CCC}$ & $\mathrm{CCC}$ & Caa2 & \\
\hline CCC- & CCC- & Caa3 & \\
\hline $\mathrm{CC}$ & CC & $\mathrm{Ca}$ & \\
\hline $\mathrm{C}$ & C & $C$ & \\
\hline $\mathrm{RD} / \mathrm{D}$ & SD/D & & Speculative \\
\hline
\end{tabular}

Source: Fitch, S\&P and Moody's.

Table 2: Long Term Sovereign Risk Ratings used by Fitch, S\&P and Moody's 


\section{LITERATURE SURVEY}

Different methods by different academicians have been conducted to investigate various factors which are determinant in credit ratings. For instance, several authors, such as Edwards (1984), Cline (1995), and Cline and Barnes (1997) agree that domestic variables, namely the gross domestic product (GDP) growth and the growth in exports are significant determinants of country spreads in developing countries.

The study of Cantor and Packer (1996) may be regarded as one of the early studies in this area. The authors analyze the determining factors and repercussions of sovereign credit ratings, by studying a cross-section of 49 countries by conducting the ordinary least squares method. The study puts forward that six factors have an important role to determine a country's credit rating, namely the per capita income, the gross domestic product (GDP) growth, the inflation rate, the external debt, the level of economic development, and the default history of the country.

Collin-Dufresne and Goldstein (2001) add other macroeconomic variables, such as the gross domestic product (GDP) growth, the volatility of stock market index, the trade balance, and the interest rates. The main goal of this study is to reveal the effect of changes in the macroeconomic factors and policy announcements on corporate bond ratings in the emerging economies, which are South Korea, China, Malaysia, India, and Taiwan.

Kose et al. (2003) state that specific country factors, such as the output growth, the investment growth, and the consumption growth possess better explanatory power for business cycle fluctuations of developing countries, compared to that of developed countries where the primary explanation is given by a "world factor" (a dynamic factor common to all aggregates, regions and countries). However, the debt markets vary among the emerging countries due to different term structure of interest rates, the policies and other economic dynamics. These authors conclude that the credit rating is primarily determined by the factors, namely the level of gross domestic product (GDP) per capita, the real gross domestic product (GDP) growth, the external debt, the level of public debt, and the government budget balance.

Afonso (2003) investigates potential determining factors of the sovereign rating credits, which are rated by Moody's and the S\&P, for a sample of 81 countries, of which 29 countries are developed and the remaining 52 countries are developing countries. The study is conducted for the year of 2001 and uses the ordinary least squares (OLS) method. Rating scales are transformed by using linear, logistic and exponential transformations. The study shows that the variables, which have statistically significant explanatory power for the credit ratings, are various parameters such as the gross domestic product (GDP) per capita, the external debt as a percentage of the exports, the level of economic development, the default history of the country, the real growth rate, and finally the inflation rate. 
Alexe et al. (2003) attempts to create a transparent, consistent, self-contained, and stable system, which will nearly approximate the major existing country risk rating systems. The Standard \& Poor country risk rating system is chosen as the benchmark for the desired system. The system is designed as composed of nine economic variables, such as the gross domestic product (GDP) per capita, the inflation rate, the trade balance, the international reserves, the fiscal balance, the export growth rate, the debt to gross domestic product (GDP), the financial depth and efficiency of the financial system, and the exchange rates, and also three political variables, such as the political stability, the government effectiveness and the corruption levels.

The study of Bissoondoyal - Bheenick (2005) spans the period of December 1995 December 1999 and employs the ordered response model. He concludes that the gross national product (GNP) per capita and the inflation rate are the key economic indicators emphasized by the credit rating agencies in determining the credit ratings. The variables, such as the gross national product (GNP) per capita, the current account balance, the inflation rate, and the level of foreign reserves are found to be important factors in the determination of ratings in developing countries.

Butler and Fauver (2006) investigate the cross-sectional determining factors of the sovereign credit ratings by measuring a sample of 86 countries as of March 2004. The authors conclude that the quality of a country's legal and political institutions, which are measured by its rule of law, voice of the people, the political stability, the government effectiveness, the corruption control, and regulatory quality, has a fundamental effect in determining the credit ratings.

Bissoondoyal - Bheenick et al. (2006) makes a comparison between the results of two methods. The methods are the case-based reasoning (CBR) and the ordered probit approach. The results of the two methods are found to be similar, which indlicate that there is consistency in the results. The findings show that the gross domestic product (GDP), the inflation rate, and the real interest rates are significant in determining the sovereign credit ratings.

The survey conducted by Afonso et al., (2007) utilizes panel estimations and random effects ordered probit methods to evaluate the effects of several macroeconomic and public governance variables for explaining and determining the sovereign debt credit ratings of 78 countries for the period of 1995-2005. The results reveal that the per capita (GDP), the real growth rate of the gross domestic product (GDP), the government debt, government effectiveness, the external debt, the external reserves, and the sovereign default indicators are found to be significantly relevant for determining the credit ratings.

Afonso et al. (2009) also investigates the determining factors of the sovereign debt ratings for 66 countries during 1996-2005, by applying ordered logit and probit plus random effects ordered probit approaches. The authors find out that the random effects ordered probit estimation is more efficient than the other two methods, since a considerable number of 
variables show up as significant, that are not picked up when using the other two methods. A recent study, conducted by the same authors (2011), aims to distinguish between short-term and long-term determining factors of a country's credit ratings by employing linear and ordered response models. The results indicate that changes in the gross domestic product (GDP) per capita, the gross domestic product (GDP) growth, the government debt, and the government budget balance have short-term impact on a country's credit ratings; while the government effectiveness, the external debt, the foreign reserves, and finally the default history are significantly important long-term determining factors.

Kalayc1, Demir and Gök (2010) express that the inflation rate, the domestic savings/gross domestic product (GDP), the external debt, and the general government budget balance excluding interest/(GDP) are significant determinants in credit ratings. The authors conclude that, Turkey deserves higher credit ratings in terms of her economic indicators, but ratings are assigned lower due to political and social factors.

Afonso, Gomes and Rother (2011) indicate that, the gross domestic product (GDP) per capita, the growth rate, the public debt and the budget balance are significant variables in the short term, while a strong government, the external debt, the foreign currency reserves, and the country's default history are determining factors in the long term for the credit ratings.

Canuto et al. (2012), find that credit ratings are over three times as sensitive to a change in the composite of legal environment, as they are to the gross domestic product (GDP) per capita, the inflation rate, the external debt per gross domestic product (GDP), and the overall economic development. They also employ linear panel models generalizing a cross section specification to panel data.

Teker et al. (2013), use a panel data set of 23 countries for the period of 1998-2010. The study estimates an ordered probit model where a dependent variable is the transformed rating categories on a scale of 1-24 and independent variables are shown. Following this, explanatory variables are reduced by exploring factor analysis that is used as new independent variables in the ordered probit regressions. Then, the factor ordered probit regressions are estimated. According to the ordered probit estimation results, the gross domestic product (GDP) per capita, the inflation rate, the public debt to gross domestic product (GDP), the Index of Economic Freedom by The Heritage Foundation and The Wall Street Journal, the Corruption Perception Index of Transparency International, and the portfolio investment to gross domestic product (GDP) variables are found to be statistically significant at the $95 \%$ confidence level.

Pretorius and Botha (2014) analyze the ratings of S\&P, Fitch and a South African based research unit called NKC Independent Economists (NKC), conducting the pooled OLS, fixed effects, random effects and ordered probit models. The study aims to investigate whether the determinants of sovereign credit ratings identified in literature are significant for African sovereigns as well. The authors prove that the external balance, the foreign reserves and the 
Corruption Perception Index are found to be significant for all of the three institutions. Moreover, the debt to gross domestic product (GDP), the fiscal balance, and the gross domestic product (GDP) growth are significant for the (NKC) ratings; the foreign direct investment to gross domestic product (GDP) and the fiscal balance are significant for Fitch ratings; and finally the debt to gross domestic product (GDP) is significant for the S\&P ratings.

\section{DATA AND METHODOLOGY}

\subsection{Data}

In this survey, credit ratings given to Turkey for the period of 2000-2014 by the major international credit rating agencies (S\&P, Fitch and Moody's) are analyzed. A dependent variable is made by denoting a change in credit ratings as 1 , or else as 0 . The aim of this study is to investigate various factors which are significantly influential in rating changes and to determine the related risk levels for each of the three agencies.

While selecting independent variables, different studies were evaluated through literature review and economic, financial and political indicators are determined. Variables with high correlation are excluded in order to avoid multicollinearity.

\begin{tabular}{|l|l|}
\hline Variables & Definition \\
\hline Gross Domestic Product & GDP \\
\hline Inflation Rate & INF \\
\hline Real Interest Rates & RIR \\
\hline Current Account Balance & CAB \\
\hline Unemployment Rate & UM \\
\hline External Debt & ED \\
\hline Stock Market Return & SMR \\
\hline Political Risk Index & PRI \\
\hline Human Development Index & HDI \\
\hline
\end{tabular}

Table 3: Descriptions of Variables

In the study, each credit rating agency is assessed independently of each other. The data for the related years are compiled from IMF World Economic Outlook Database and IMF Articlle IV country reports. As the political instability measure, Political Risk Index (PRI) which is obtained from International Country Risk Guide (ICRG) and developed by The PRS Group is used. This index is composed of 12 components which are government stability, socioeconomic conditions, investment profile, internal conflict, external conflict, corruption, military in politics, religious tensions, law and order, ethnic tension, democratic accountability and bureaucracy quality. Before cited index is chosen due to the fact that it is the most frequently used measure of corruption in academic research, as indicated by Alesina and Weder (1999). Human Development Index (HDI) is developed and released by the United Nations since 1990. HDI is composed of education, health, and income indicators and while being one of the most frequently used measures, new indices that use different methodologies emerged over time. 


\subsection{Logistic Regression}

In logistic regression, a single outcome variable $Y_{i}(i=1, \ldots, n)$ follows a Bernoulli probability function that takes on the value 1 with probability $\pi_{i}$ and 0 with probability $1-\pi_{i}$. Then $\pi_{i}$ varies over the observations as an inverse logistic function of a vector $\mathbf{x}_{i}$ which includes a constant and $k-1$ explanatory variables: $Y_{i} \sim \operatorname{Bernoulli}\left(Y_{i} \mid \pi_{i}\right)$

$\pi_{i}=\frac{1}{1+e^{-\mathbf{x}_{i} \beta}}$

The Bernoulli has probability function $P\left(Y i \mid \pi_{i}\right)=\pi_{i}^{Y_{i}}\left(1-\pi_{i}\right)^{1-Y_{i}}$. The unknown parameter $\boldsymbol{\beta}=\left(\beta_{0}, \boldsymbol{\beta}_{1}^{\prime}\right)^{\prime}$ is a $k \times 1$ vector, where $\beta_{0}$ is a scalar constant term and $\boldsymbol{\beta}_{1}$ is a vector with elements corresponding to the explanatory variables. An alternative way to define the same model is by imagining an unobserved continuous variable $Y_{i}^{*}$ distributed according to a logistic density with mean $\mu_{i}$. Then $\mu_{i}$ varies over the observations as a linear function of $\mathbf{x}_{i}$. The model would be very close to a linear regression if $Y_{i}^{*}$ were observed:

$Y_{i}^{*} \sim \operatorname{Logistic}\left(Y_{i}^{*} \mid \mu_{i}\right)$

$\mu_{i}=\mathbf{x}_{i} \boldsymbol{\beta}$

where $\operatorname{Logistic}\left(Y_{i}^{*} \mid \mu_{i}\right)$ is the one-parameter logistic probability density.

$$
P\left(Y_{i}^{*}\right)=\frac{e^{-\left(Y_{i}^{*}-\mu_{i}\right)}}{\left(1+e^{-\left(Y_{i}^{*}-\mu_{i}\right)}\right)^{2}}
$$

Unfortunately, instead of observing $Y_{i}^{*}$, its dichotomous realization $Y_{i}$, where $Y_{i}=1$ if $Y_{i}^{*}>0$, and $Y_{i}=0$ if $Y_{i}^{*} \leq 0$.

The model remains the same because

$$
\begin{aligned}
\operatorname{Pr}\left(Y_{i}=1 \mid \boldsymbol{\beta}\right) & =\pi_{i}=\operatorname{Pr}\left(Y_{i}^{*}>0 \mid \boldsymbol{\beta}\right) \\
& =\int_{0}^{\infty} \operatorname{Logistic}\left(Y_{i}^{*} \mid \mu_{i}\right) d Y_{i}^{*}=\frac{1}{1+e^{-\mathbf{x}_{i} \boldsymbol{\beta}}}
\end{aligned}
$$

which is exactly as in Eq. (1). It is also known that the observation mechanism, which turns the continuous $Y^{*}$ into the dichotomous $Y_{i}$, generates most of the mischief. That is, simulations were run, trying to estimate $\beta$ from an observed $Y^{*}$ and model 2 and it is found that maximum-likelihood estimation of $\beta$ is approximately unbiased in small samples. The parameters are estimated by maximum likelihood, with the likelihood function formed by assuming independence over the 
observations: $L(\boldsymbol{\beta} \mid \mathbf{y})=\prod_{i=1}^{n} \pi_{i}^{Y_{i}}\left(1-\pi_{i}\right)^{1-Y_{i}}$. By taking logs and using Eq. (1), the log-likelihood simplifies to

$$
\begin{aligned}
\ln L(\boldsymbol{\beta} \mid \mathbf{y}) & =\sum_{\left\{Y_{i}=1\right\}} \ln \left(\pi_{i}\right)+\sum_{\left\{Y_{i}=0\right\}} \ln \left(1-\pi_{i}\right) \\
& =-\sum_{i=1}^{n} \ln \left(1+e^{\left(1-2 Y_{i}\right) \mathbf{x}_{i} \beta}\right)
\end{aligned}
$$

Maximum-likelihood logit analysis then works by finding the value of $\boldsymbol{\beta}$ that gives the maximum value of this function, which we label $\hat{\boldsymbol{\beta}}$. The asymptotic variance matrix, $\boldsymbol{V}(\hat{\boldsymbol{\beta}})$, is also retained to compute standard errors. When observations are selected randomly, or randomly within strata defined by some or all of the explanatory variables, $\hat{\boldsymbol{\beta}}$ is consistent and asymptotically efficient (except in degenerate cases of perfect collinearity among the columns in $\mathbf{X}$ or perfect discrimination between zeros and ones). That in rare events data ones are monre statistically informative than zeros can be seen by studying the variance matrix,

$$
\boldsymbol{V}(\hat{\boldsymbol{\beta}})=\left[\sum_{i=1}^{n} \pi_{i}\left(1-\pi_{i}\right) \mathbf{x}_{i}^{\prime} \mathbf{x}_{i}\right]^{-1}
$$

The part of this matrix affected by rare events is the factor $\pi_{i}\left(1-\pi_{i}\right)$. Most rare events applications yield small estimates of $\operatorname{Pr}\left(Y_{i}=1 \mid x_{i}\right)=\pi_{i}$ for all observations. However, if the logit model has some explanatory power, the estimate of $\pi_{i}$ among observations for which rare events are observed (i.e., for which $Y_{i}=1$ ) will usually be larger than among observatins for which $Y_{i}=\mathbf{0}$. The result is that $\pi_{i}\left(1-\pi_{i}\right)$ will usually be larger for ones than zeros, and so the variance (its inverse) will be smaller. In this situation, additional ones will cause the variance to drop more and hence are more informative than additional zeros (Allison, 2000:22-25).

\subsection{Empirical Results}

Data is analyzed with SPSS 18.0 (SPSS Inc, Chicago, II) software package. Logistic regression results are obtained using the Forward Wald method, and the maximum number of iterations is set to 20 .

Omnibus test measures the ability of all explanatory variables in the model for estimating the dependent variable. After the analysis, $\mathrm{p}<0.05$ value is achieved and thus the hypothesis $\mathrm{H}_{1}$ is accepted. As a result, it is determined that at least one variable has a significant relationship with the dependent variable, hence it is determined that the model fits the data well. Hosmer-Lemeshow chisquare statistic examines the logistic regression model as a whole by testing if all logit coefficients except for the invariable equal to zero. For Hosmer-Lemeshow test, which is fundamental for the model's goodness of fit, the value $\mathrm{p}>0.05$ is achieved. Therefore the $\mathrm{H}_{0}$, which states the model's goodness of fit, can not be rejected and the model is fit for analysis. In logistic regression estimation, 
stepwise estimation process is chosen and in each step $-2 \log$ likelihood $=634.249$ value reached its minimum and Cox \& Snell R Square $=0.635$ and Nagelkerke R Square $=0.659$ values reached their maxima, therefore showed the significance of the model. In addition, the model's rate of classification was obtained as $87.2 \%$ in Table 4 .

\begin{tabular}{|l|l|l|l|l|l|l|}
\hline & B & S.E. & Wald & Df & Sig. & Exp(B) \\
\hline GDP & 1.045 & .423 & 6.110 & 1 & .013 & 2.843 \\
INF & -.094 & .119 & .620 & 1 & .431 & .911 \\
RIR & .194 & .250 & .600 & 1 & .438 & 1.214 \\
CAB & .925 & .233 & 15.781 & 1 & .000 & 2.523 \\
UM & .341 & .552 & .382 & 1 & .537 & .711 \\
ED & -.224 & .437 & .261 & 1 & .609 & .800 \\
SMR & -.931 & .233 & 16.012 & 1 & .000 & 2.536 \\
PRI & .335 & .152 & 4.830 & 1 & .028 & 1.397 \\
HDI & .172 & 1.975 & .008 & 1 & .930 & 1.188 \\
Constant & 1.309 & .935 & 1.962 & 1 & .161 & .270 \\
\hline
\end{tabular}

Significance Tests for Logistic Regression Model:

Omnibus Test for Model Coefficients : Chi-Square Value for the Model $=489.350$, Prob $=$ 0.000

-2 Log likelihood = 634,249; Cox \& Snell R Square= $0.635 ;$ Nagelkerke R Square $=0.659$

Hosmer and Lemeshow Test: Chi-Square Value $=7.885$, Prob $=0.228$

Table 4 : Logistic Regression Estimation Results for S\&P

\begin{tabular}{|c|c|c|c|c|c|c|}
\hline & B & S.E. & Wald & Df & Sig. & $\operatorname{Exp}(B)$ \\
\hline GDP & -1.305 & .219 & 35.516 & 1 & .000 & 3.688 \\
\hline INF & .108 & .289 & .141 & 1 & .708 & 1.114 \\
\hline $\mathrm{RIR}$ & .631 & .488 & 1.670 & 1 & .196 & 1.880 \\
\hline$C A B$ & .100 & .110 & .827 & 1 & .363 & 1.105 \\
\hline UM & -.890 & .186 & 22.875 & 1 & .000 & .411 \\
\hline ED & .229 & .084 & 7.452 & 1 & .006 & 1.257 \\
\hline SMR & -.252 & .446 & .320 & 1 & .572 & .777 \\
\hline PRI & .814 & .184 & 19.546 & 1 & .000 & 2.257 \\
\hline $\mathrm{HDI}$ & -1.730 & 1.417 & 1.490 & 1 & .222 & .177 \\
\hline Constant & -8.529 & 3.238 & 6.936 & 1 & .008 & .000 \\
\hline \multicolumn{7}{|c|}{ Significance Tests for Logistic Regression Model: } \\
\hline \multicolumn{7}{|c|}{$\begin{array}{l}\text { Omnibus Test for Model Coefficients : Chi-Square Value for the Model }=534.223 \text {, Prob }= \\
0.015\end{array}$} \\
\hline \multicolumn{7}{|c|}{-2 Log likelihood = $701.234 ;$ Cox \& Snell R Square= $0.618 ;$ Nagelkerke R Square $=0.602$} \\
\hline \multicolumn{7}{|c|}{ Hosmer and Lemeshow Test: Chi-Square Value $=6.921$, Prob $=0.194$} \\
\hline
\end{tabular}

Table 5: Logistic Regression Estimation Results for Moody's 
Statistically significant variables to influence a change in credit rating for S\&P are GDP, CAP, SMR and PRI. Considering Exp (B) values, the biggest risk factor to influence the probability of a change in the credit rating is the GDP variable (approximately 2.84-fold increase), the second biggest risk factor is SMR (2.53-fold increase), the third biggest risk factor is CAB (2.52-fold increase) and finally PRI (1.39-fold increase). It can be noticed that, economic and financial factors have a higher importance than the political risk factor in a change in S\&P's credit rating.

Because the omnibus test results in $\mathrm{p}<0.05$, the hypothesis $\mathrm{H}_{1}$ is accepted and it is determined that at least one variable is significantly related to the independent variable, hence the model fits the data well. For Hosmer-Lemeshow test, which is fundamental for the model's goodness of fit, the value $\mathrm{p}>0.05$ is achieved. Therefore the $\mathrm{H}_{0}$, which states the model's goodness of fit, can not be rejected and the model is fit for analysis. In logistic regression estimation, stepwise estimation process is chosen and in each step $-2 \log$ likelihood $=701.234$ value reached its minimum and Cox $\&$ Snell $\mathrm{R}$ Square $=$ 0.618 and Nagelkerke R Square $=0.602$ values reached their maxima, therefore showed the significance of the model. In addition, the model's rate of classification was obtained as $89.7 \%$ in Table 5 .

Statistically significant variables to influence a change in credit rating for Moody's are GDP, UM, ED and PRI. Considering Exp (B) values, the biggest risk factor to influence the probability of a change in the credit rating is the GDP variable (approximately 3.68-fold increase), the second biggest risk factor is PRI (2.25-fold increase), the third biggest risk factor is ED (1.25-fold increase) and finally UM ( 0.41 -fold increase). It can be noticed that, for Moody's, the political risk factor ranks higher than for S\&P.

\begin{tabular}{|c|c|c|c|c|c|c|}
\hline & B & S.E. & Wald & Df & Sig. & $\operatorname{Exp}(B)$ \\
\hline GDP & 1.702 & .330 & 26.528 & 1 & .000 & 5.484 \\
\hline INF & .095 & .569 & .028 & 1 & .868 & 1.099 \\
\hline RIR & .814 & .184 & 19.546 & 1 & .000 & 2.257 \\
\hline $\mathrm{CAB}$ & -.003 & .252 & .000 & 1 & .991 & .997 \\
\hline UM & -1.673 & .813 & 4.236 & 1 & .040 & .188 \\
\hline ED & 1.577 & .303 & 27.148 & 1 & .000 & 4.839 \\
\hline SMR & -1.237 & 1.057 & 1.368 & 1 & .242 & .290 \\
\hline PRI & .818 & .177 & 21.377 & 1 & .000 & 2.266 \\
\hline $\mathrm{HDI}$ & -.961 & .653 & 2.164 & 1 & .141 & .383 \\
\hline Constant & -12.383 & 2.721 & 20.707 & 1 & .000 & .000 \\
\hline \multicolumn{7}{|c|}{ Significance Tests for Logistic Regression Model: } \\
\hline \multicolumn{7}{|c|}{$\begin{array}{l}\text { Omnibus Test for Model Coefficients : Chi-Square Value for the Model }=521.980, \text { Prob }= \\
0.021\end{array}$} \\
\hline \multicolumn{7}{|c|}{-2 Log likelihood $=669.249 ;$ Cox \& Snell R Square $=0.642 ;$ Nagelkerke R Square $=0.651$} \\
\hline \multicolumn{7}{|c|}{ Hosmer and Lemeshow Test: Chi-Sqiare Value $=8.526$, Prob $=0.286$} \\
\hline
\end{tabular}

Table6: Logistic Regression Estimation Results for Fitch 
Because the omnibus test results in $\mathrm{p}<0.05$, the hypothesis $\mathrm{H}_{1}$ is accepted and it is determined that at least one variable is significantly related to the independent variable, hence the model fits the data well. For Hosmer-Lemeshow test, which is fundamental for the model's goodness of fit, the value $\mathrm{p}>0.05$ is achieved. Therefore the $\mathrm{H}_{0}$, which states the model's goodness of fit, can not be rejected and the model is fit for analysis. In logistic regression estimation, stepwise estimation process is chosen and in each step -2 Log likelihood $=669.294$ value reached its minimum and Cox \& Snell R Square= 0.642 and Nagelkerke $\mathrm{R}$ Square $=0.651$ values reached their maxima, therefore showed the significance of the model. In addition, the model's rate of classification was obtained as $84.1 \%$ in Table 6.

Statistically significant variables to influence a change in credit rating by Fitch are GDP, RIR, ED and PRI. Considering Exp (B) values, the biggest risk factor to influence the probability of a change in the credit rating is the GDP variable (approximately 5.48-fold increase), the second biggest risk factor is ED (4.83-fold increase), the third biggest risk factor is PRI (2.26-fold increase) and finally RIR (2.25fold increase). In contrast to other 2 agencies, the variable RIR is determined to be statistically significant.

As a conclusion, GDP and PRI variables are equally significant for each of the three agencies. Moreover, it is determined that other variables are also significant. Even though variables are different, the headings did not change and it is observed that for each of the three agencies, the GDP variable is the primary significant risk factor.

\section{CONCLUSION}

Credit rating agencies play an important role in the economy for capital markets, investing companies either for direct investments and/or portfolio investments, and financial intermediary institutions. In this context, the primary issues are the determination of interest rates according to the risk they bear, the establishment of continuing creditworthiness of the financial and economic system without any government guarantee, the improvement of relations/transactions with the international finance environment, and decreasing the costs of borrowing from external sources.

Credit rating is not a determining factor only for financial markets in the economies which are in need of sources and financing in general and also from external sources. The reason that financial markets are mentioned and considered primarily is because of the fact that, the inflows and outflows of funds in a country are extremely and suddenly affected by the economic variables due to high activities in financial markets. The foreign direct investments, which possess longer terms and lower activity nature, are also effected from the credit ratings. Although credit ratings assigned by the rating agencies are only a point of view, they may affect the investment decisions of foreign investors. Moreover, all financial sources for investments, that is, the ability of domestic investors for conducting business, their capability to borrow from external sources, their trading transactions as buying and selling domestic and foreign bonds and the facility of lower financing costs necessary for big infrastructure projects that require external financing from international sources, are all influenced by credit ratings given by those agencies.

Rather than obtaining current economic and financial data in an economy, the basic need for credit rating agencies comes from the expectations that the agencies will provide safer and more realistic signals about the future conditions of financial securities which are assessed by those agencies' 
ratings. Thus, it is great importance that reports published by the credit rating agencies present true and safe information, not only for the agency, but also for the country and the company rated by the agency.

This survey puts forward various economic, financial, and political factors that significantly influence changes in the credit ratings assigned by the S\&P, Moody's and Fitch to Turkey for the period of 2000-2014, by employing the logistic regression. Equally significant variables for the each of three agencies are found out as the gross domestic product (GDP) and political risk index (PRI). For S\&P, the statistically significant variables which influence the probability of a change in S\&P's ratings, as in the order of significance level, are the gross domestic product (GDP), the stock market return (SMR), the current account balance (CAB) and, the political risk index (PRI); while for Moody's, in the order of significance level, they are the gross domestic product (GDP), the political risk index (PRI), the external debt (ED), and the unemployment rate (UM), and finally for Fitch, in the order of significance level, the gross domestic product (GDP), the external debt (ED), the political risk index (PRI), and the real interest rates (RIR). The external debt (ED) variable is not significant for a rating change given by $\mathrm{S} \& \mathrm{P}$, whereas it is a significant variable both for Moody's and Fitch.

Consequently, this study determines in detail that, along with the basic economic and financial parameters, the political risk factors are also significantly effective for changes in credit ratings for Turkey for 2000-2014. Although credit ratings are assigned as "opinions", which are the results of credit rating agencies' methodologies that are heavily based on financial indicators, there exists no clear line among the subjective and objective factors effecting the ratings. The inconsistency among various criteria, which credit rating agencies consider in determining the ratings, leads to the belief that analysts prioritize the subjective assessments in their decisions, while tarnishing the credibility and trustworthiness of rating agencies and their function in providing a signalling mechanism for the future. Credit rating agencies are criticized for not being able to respond to changing and current economic trends, due to the same rating methodologies that are utilized over long years. Moreover, there exist differences in the structure and nature of countries, therefore using a single methodology for all countries has not been compatible to the global financial system, in terms of validity. This situation tarnishes the credibility of credit rating agencies and sparks a debate whether those institutions should be reorganized and have more increased transparency. 


\section{REFERENCES}

- Afonso, A. (2003). Understanding the Determinants of Sovereign Debt Ratings: Evidence for the Two Leading Agencies. Journal of Economics and Finance, 27(1), 56-74.

- Afonso, A., Gomes, P. M., Rother, P. (2007). What Hides Behind Sovereign Debt Ratings. $\quad$ ECB Working Paper No. 771.

- Afonso, A., Gomes, P. M., Rother, P. (2009). Ordered Response Models For Sovereign Debt Ratings. Applied Economic Letters, 16(8), 769-773.

- Afonso, A., Gomes, P. M., Rother, P. (2011). Short and Long-Run Determinants of Sovereign Debt Credit Ratings. International Journal of Finance \& Economics, 16(1), 1-15.

- Alexe, S., Hammer, P. L., Kogan, A., Lejeune, M. A. (2003). A Non-Recursive Regression Model For Country Risk Rating. RUTCOR-Rutgers University Research Report RRR, 9, 1-40.

- Allison, P. D. (2000). Logistic Regression Using The SAS System. 2. Edition, Cary: SAS Institute.

- Bissoondoyal-Bheenick, E. (2005). An Analysis of the Determinants of Sovereign Ratings. Global Finance Journal. 15(3), 251-280.

- Bissoondoyal-Bheenich, E., Brooks, R., Yip, A. Y. N. (2006). Determinants of Sovereign Ratings: A Comparison of Case-Based Reasoning and Ordered Probit Approaches. Global Finance Journal, 17(1), 136-154.

- Butler, A. W., Fauver, L. (2006). Institutional Environment and Sovereign Credit Ratings. Financial Management, 35(3), 53-79.

- Brunner, A., Krahnen, J., P., Weber M. (2000). Information Production in Credit Relationships: On the Role of Internal Ratings in Commercial Banking. Center for Financial Studies, Frankfurt.

- Canuto, O., Dos Santos, P. F. P., Porto, P. C. D. S. (2012). Macroeconomics and Sovereign Risk Ratings. Journal of International Commerce, Economics and Policy (JICEP), 3(2), 11-25.

- Cantor, R., Packer, F. (1997). Determinants and Impact of Sovereign Credit Ratings. FRBNY Economic Policy Review, October, 37-54.

- Cline, W. R. (1995). International Debt Reexamined. Peterson Institute Press: All Books, Peterson Institute for International Economics, No: 46.

- Cline, W. R., Barnes, K. J. S. (1997). Spreads and Risk in Emerging Market Lending. IIF Research Paper, No: 97-1.

- Collin-Dufresne, P., Goldstein, R., Martin, S. (2001). The Determinants of Credit Spread Changes. Journal of Finance, 56, 2177-2207.

- Edwards, S. (1984). LDC Foreign Borrowing and Default Risk: An Empirical Investigation. American Economic Review, 74, 726-734.

- Gallati, R. (2003). Risk Management and Capital Adequacy. The McGraw-Hill Companies, Inc, New York.

- Kose, M., Otrok, C., Whiteman, C. (2003). International Business Cycles:World, Region, and Country-Specific Factors. American Economic Review, 93(4), 12161239.

- Nye, R. P., Eke, S. (2004). Türkiye'de Kredi Derecelendirmesi. Active Bankacılık ve Finans Dergisi, 1(2), 10-19.

- Pretorius, M., Botha, I. (2014). A Panel Ordered Response Model for Sovereign Credit Ratings in Africa. ERSA Working Paper No. 464, 1-16. 
- Scott, H. S. (2005). Capital Adequacy Beyond Basel, Banking, Securities, and Insurance. Oxford University Press U.S.A.

- Sümer, K. K. (2003) Sosyal Bilimler Araştırmalarında Tasnif Edilmiş Bağımlı Değişkenler Sosyoloji Konferansları Dergisi, Sayı: 27, 75-92

- Tattersall, J., Smith, R. (2005). A Practitioner's Guide to The Basel Accord. City\&Financial Publishing, UK.

- Teker, D., Pala, A., Kent, O. (2013). Determination of Sovereign Rating: Factor Based Ordered Probit Models for Panel Data Analysis Modelling Framework. International Journal of Economics and Financial Issues. Vol. 3. No. 1, 122-132.

- Ward, J. (2002). The New Basel Accord and Developing Countries: Problems and Alternatives. ESRC Centre for Business Research Cambridge University WorkingPaper No.4, 1-89. 